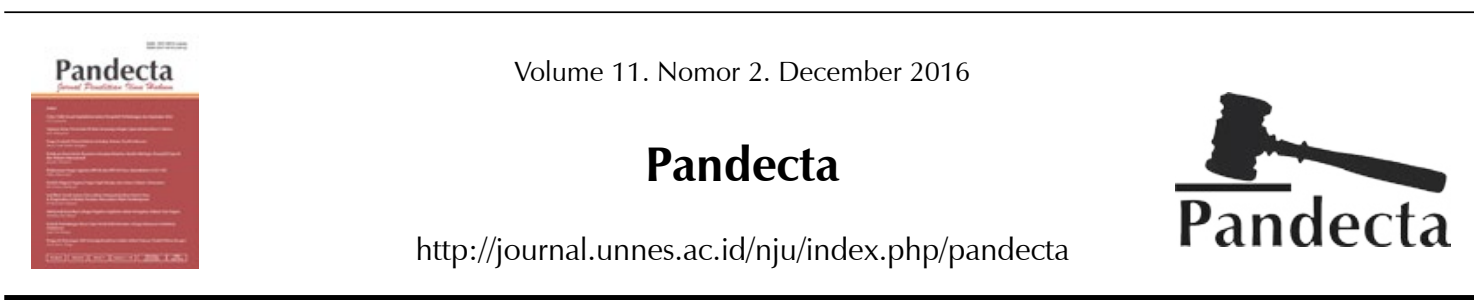

\title{
Pola Persaingan Antara Hukum dengan Politik dalam Pembentukan Peraturan Perundang-undangan
}

\author{
Ricca Anggraeni $\bowtie$
}

Fakultas Hukum Universitas Diponegoro

DOI: http://dx.doi.org/10.15294/pandecta.v11i1.7833

\section{Info Artikel}

Article History:

Received : June 2016;

Accepted: November 2016

Published: December 2016

Keywords:

Ideology; pancasila; political, establishment of legislation

\section{Abstrak}

Hirarki peraturan perundang-undangan Indonesia, secara normatif diatur dalam suatu peraturan perundang-undangan mulai tahun 1966 sampai dengan tahun 2011. Hal ini mengukuhkan bangunan hukum positif di Indonesia. Pancasila sebagai Grundnorm ditempatkan sebagai norma yang memiliki realitas ideal yang diidentikkan dengan keadilan. Berbeda dengan Staatsfundamentalnorm, yang menempatkan Pancasila sebagai ideologi untuk melegitimasi atau membatalkan suatu produk hukum. Oleh karena itu, pembentuk undang-undang ketika bersinggungan dengan persoalan politik, maka harus menempatkan Pancasila sebagai ideologi untuk membuat hukum yang dianggap adil. Penelitian ini akan menganalisis apakah Pancasila sebagai Grundnorm atau Staatsfundamentalnorm membawa persaingan antara politik dan hukum, sehingga menjadi bias keadilan; bagaimana pola persaingan antara hukum dengan politik dalam pembentukan undang-undang; dan apakah pola persaingan itu menempatkan Pancasila dalam realitas ideal sekaligus ideologi. Metode penelitian yang digunakan adalah penelitian hukum doktrinal, karena bukan hanya berorientasi pada norma, melainkan juga pada prinsip dan doktrin untuk menganalisis pola persaingan antara politik dan hukum dalam pembentukan undang-undang.

\begin{abstract}
The hierarchy of Indonesian laws, normatively regulated in a legislation from 1966 to 2011. This confirms the building of positive law in Indonesia. Pancasila as a Grundnorm is placed as a norm that has an ideal reality that is identified with justice. In contrast to Staatsfundamentalnorm, which places Pancasila as an ideology to legitimize or cancel a legal product. Therefore, the legislator when it comes to political issues, then must place Pancasila as an ideology to make law that is considered fair. This paper will analyze whether Pancasila as a Grundnorm or a Staatsfundamentalnorm brings competition between politics and law, so that it becomes a bias of justice; How the pattern of competition between law and politics in the formation of laws; And whether the pattern of competition puts Pancasila in both ideal and ideological reality. The research method used is doctrinal legal research, because not only oriented to the norm, but also on principles and doctrines to analyze the pattern of competition between politics and law in the formation of laws.
\end{abstract}




\section{Pendahuluan}

Pancasila menjadi sesuatu yang penting dalam kehidupan berbangsa dan bernegara Indonesia. Pancasila dianggap sebagai landasan dasar bernegara yang harus ditetapkan lebih awal sebelum Negara Indonesia berdiri. Sejak ditetapkannya sampai saat ini, Pancasila sudah mengalami pasang surut gelombang penerapannya secara historis berdasarkan rezim-rezim yang berkuasa. Dimulai dari rezim Soekarno yang menerapkan Pancasila sebagai weltanschauung (konstruksi sebagai kompromi politik dan sosial), kemudian bergeser ke Soeharto yang menerapkan Pancasila sebagai ultimate goal, gagasan yang utuh sebagai ideologi negara yang mutlak memiliki kebenaran tunggal. Bahkan Pancasila menjadi sumber dari segala sumber hukum serta menafsirkannya dengan Pedoman penghayatan dan Pengamalan Pancasila (P4). Pada akhirnya, P4 menjadi alat legitimasi negara untuk menafsirkan Pancasila, bahkan dapat mengontrol potensi penyelewengan dari tafsiran resmi. Keadaan semacam ini membalikkan rezom Soeharto dan menggantikannya dengan rezim baru hasil dari sebuah gerakan yang disebut reformasi. Rezim kekuasaan hasil reformasi ini berusaha untuk mereposisi Pancasila, bahwa Pancasila tidak hanya dipandang sebagai ideologi an-sich, melainkan juga sebagai dasar negara, konsensus dasar, identitas kultural, dan visi bangsa.

Namun, peletakan Pancasila sebagai sumber dari segala sumber hukum tetap berlanjut hingga saat ini. Undang-Undang Nomor 12 Tahun 2011 tentang Pembentukan Peraturan Perundang-undangan, melalui Pasal 2 tetap mengatur hal tersebut, setelah sebelumnya diatur melalui Undang-Undang Nomor 10 Tahun 2004 tentang Pembentukan Peraturan Perundang-undangan yang juga melalui Pasal 2. Undang-undang itu tidak mengubah sama sekali konsep Pancasila sebagai sumber dari segala sumber hukum yang sebelumnya diatur melalui Pasal 1 ayat (3) Ketetapan Nomor III/MPR/2000 tentang Sumber Hukum dan Tata Urutan Peraturan Perundang-undangan, dan Lampiran I Penjelasan Ketetapan MPRS Nomor XX/ MPRS/1966 tentang Memorandum DPR-GR
Mengenai Sumber Tertib Hukum RI dan Tata Urutan Perundangan RI dan Skema Kekuasaan DiDalam Negara Republik Indonesia.

Dengan adanya ketentuan tersebut semakin menguatkan bahwa Indonesia dalam mengukuhkan bangunan hukum positifnya berpondasikan pada The Pure Theory of Law yang disampaikan oleh Hans Kelsen dan theorie vom stufenaufbau der rechtsordnung yang disampaikan oleh Hans Nawiasky. Namun, alih-alih memberikan kepastian hukum demi tertib sosial, justru kebingungan terjadi ketika ada tarik-menarik dalam persaingan antara hukum dan politik yang ditimbulkan oleh peletakkan Pancasila sebagai Grundnorm dalam teori Kelsen, sekaligus sebagai Staatsfundamentalnorm menurut teorinya Nawiasky. Bias tersebut terjadi ketika begitu saja Grundnorm dan Staatsfundamentalnorm secara sederhana dipahami sebagai norma tertinggi yang menjadi sumber dari segala sumber hukum, padahal pemahaman antara Grundnorm dengan Staatsfundamentalnorm berbeda.

Grundnorm dalam teorinya Kelsen adalah suatu "pengandaian" ada yang tertinggi dan terakhir, sehingga norma-norma sebagai objek dari hukum bukan hanya merealisasikan nilai-nilai keadilan melainkan menjadi sebuah upaya untuk mewujudkan nilai-nilai yang ditetapkan di dalam norma hukum itu sendiri (Dimyati dan Wardiono, 2014:4142). Sedangkan Staatsfundamentalnorm menurut Nawiasky diartikan sebagai norma fundamental negara yang menjadi sumber penjabaran dari pembentukan norma di suatu negara. Grundnorm didorong untuk tidak melayani kepentingan politik siapapun dengan memberikan alat-alat ideologis untuk melegitimasi atau membatalkan kelompok sosial yang ada.

Berdasarkan pemahaman tersebut, maka ketika Pancasila diposisikan sebagai Grundnorm, maka Pancasila menjadi basis nilai yang "diandaikan" oleh semua bangsa Indonesia. Sedangkan, ketika menjadi Staatsfundamentalnorm, maka Pancasila menjadi norma fundamental negara yang identik dengan ideologi sebagai sumber penjabaran dari seluruh norma hukum di Indonesia. Artinya, kepentingan dapat bermain dalam ranah 
Staatsfundamentalnorm, karena dapat menjadi alat untuk melayani kepentingan politik dalam melegitimasi dan membatalkan kelompok sosial yang ada. Dengan demikian, maka ada tarik-menarik ketika Pancasila diposisikan sebagai Grundnorm dan sekaligus sebagai Staatsfundamentalnorm. Persaingan itu begitu kentara dalam muatan norma hukum di Indonesia dalam ranah pembentukan undang-undang. Misalnya saja dalam Undang-Undang Sumber Daya Air yang dibatalkan oleh Mahkamah Konstitusi. Pemboncengan-pemboncengan kepentingan kapitalis sangat diakomodasi melalui norma hukum yang tercantum dalam undang-undang itu dengan membuka peluang privatisasi dan komersialisasi pihak swasta atas pengelolaan sumber daya air yang merugikan masyarakat sebagai pengguna air.

Berdasarkan hal tersebut, maka Staatsfundamentalnorm identik dengan ideologi yang dimaksud pada teori Hegemoninya Gramci yang dibangun di atas pentingnya ide karena tidak mencukupinya kekuatan fisik dalam mengontrol sosial politik. Menurut Gramci, ideologi menjadi penting agar yang dikuasai mematuhi penguasa dan harus merasa mempunyai serta menginternalisasi nilainilai serta norma yang dibuat oleh penguasa. Oleh karena itu, melalui konsep hegemoni, kekuasaan harus dilanggengkan melalui dua perangkat kerja, yaitu aparat pemerintah melalui law enforcement, dan perangkat kerja yang mampu membujuk masyarakat untuk taat pada penguasa melalui kehidupan beragama, pendidikan, kesenian dan keluarga (Beilharz, 2005: 203).

Berdasarkan hal tersebut, maka paper ini akan menganalisis apakah Pancasila sebagai Grundnorm atau Staatsfundamentalnorm telah membawa pada pola persaingan antara politik dan hukum, sehingga menjadi bias keadilan; bagaimana pola persaingan antara hukum dengan politik dalam pembentukan undang-undang; dan apakah pola persaingan itu menempatkan Pancasila dalam realitas ideal sekaligus ideologi.

\section{Metode Penelitian}

Pertanyaan tersebut dicari solusinya melalui metode penelitian hukum doktrinal, karena penelitian ini bukan hanya sekedar berorientasi pada norma, melainkan menembus pada prinsip dan doktrin untuk membaca narasi pola persaingan antara politik dan hukum dalam pembentukan undang-undang. Jenis data yang digunakan dalam penlitian ini ialah data sekunder yang dianalisis dengan menggunakan metode kualitatif. Dengan demikian, tujuan dari penelitian ini ialah untuk mengetahui konsekuensi Pancasila ketika diposisikan sebagai Grundnorm atau Staatsfundamentalnorm dengan pola persaingan antara politik dan hukum, serta mendeskripsikan pola persaingan antara politik dan hukum dalam pembentukan undang-undang, dan memberikan gambaran kemungkinan Pancasila diposisikan oleh pola persaingan itu sebagai realitas ideal sekaligus ideologi.

\section{Hasil Penelitian dan Pembahasan}

Pola Persaingan Antara Politik dan Hukum Sebagai Konsekuensi Kedudukan Pancasila Sebagai Grundnorm atau Staatsfundamentalnorm

Pancasila sejak ditetapkan sebagai dasar dari Negara Republik Indonesia pada tanggal 01 Juni 1945 telah mengalami pasang surut penerapannya. Rezim Orde Lama dan Orde Baru menerapkan Pancasila secara sakral dan menjadikannya legitimasi politis sebagai sarana untuk mempertahankan kekuasaan. Di rezim Orde Lama, Pancasila menjadi dasar dikembangkannya doktrin Manipol Usdek dan Nasakom. Setelah itu, Pancasila tetap tidak dijadikan way of life, melainkan dipelintir sebagai asas tunggal yang harus dilaksanakan secara murni dan konsekuen, dan Orde Baru sebagai pemerintah pada masa itu, mengklaim dirinya sebagai pelaksana dari Pancasila, sehingga identik dengan Pancasila. Oleh karena itu, perlawanan terhadap pemerintah dianggap sebagai perlawanan terhadap Pancasila yang harus dihentikan dan dihukum berdasarkan dalih menentang ide-ide Pancasila (Kaelan, 2012: 2-3).

Keadaan tersebut dijungkirbalikan oleh gerakan reformasi yang menginginkan adanya perubahan di segala bidang. Akibatnya ialah, Pancasila yang terlanjur terdoktrin 
sebagai alat legitimasi politik dan kekuasaan menjadi "barang" yang canggung untuk didekati, bahkan cenderung ditinggalkan dan dilupakan. Jalan yang telah ditentukan oleh Bangsa Indonesia dalam kehidupan berbangsa dan bernegara, sepertinya tergerus oleh tarik-menarik persaingan kepentingan dari kelompok penguasa itu sendiri. Dengan kata lain, Bangsa Indonesia disesatkan oleh bangsanya sendiri dalam membaca arah jalan, sehingga bukan hal yang mengherankan bila sampai saat ini Bangsa Indonesia kebingungan menentukan arah tujuan kehidupan bangsanya.

Apakah fenomena tersebut sebagai sebab atau sebagai salah satu permasalahan yang harus juga dicarikan solusinya, karena upaya untuk menjadikan Pancasila sebagai dasar dan landasan bernegara sampai saat ini terus dilakukan meskipun misleading tetap tidak terhindarkan. Diantaranya melalui upaya memposisikan Pancasila sebagai sumber hukum dari seluruh hukum yang ada di Indonesia. Upaya itu telah dimulai sejak Orde Baru menancapkan kuku-kukunya sebagai penguasa, tahun 1966 melalui Lampiran I Penjelasan Ketetapan MPRS Nomor XX/MPRS/1966 tentang Memorandum DPR-GR Mengenai Sumber Tertib Hukum RI dan Tata Urutan Perundangan RI dan Skema Kekuasaan DiDalam Negara Republik Indonesia, menyatakan bahwa Pancasila sebagai sumber dari segala sumber hukum. Upaya itu dilanjutkan melalui Pasal 1 ayat (3) Ketetapan MPR Nomor III/ MPR/2000 tentang Sumber Hukum dan Tata Urutan Peraturan Perundang-undangan yang juga menyatakan bahwa Pancasila sebagai sumber dari segala sumber hukum, lalu diteruskan oleh Pasal 2 Undang-Undang Nomor 10 Tahun 2004 tentang Pembentukan Peraturan Perundang-undangan yang mencabut keberlakuan Ketetapan MPR Nomor III/ MPR/2000, dan saat ini terus dipancangkan Pancasila sebagai sumber dari segala sumber hukum oleh Pasal 2 Undang-Undang Nomor 12 Tahun 2011 tentang Pembentukan Peraturan Perundang-undangan yang menggantikan Undang-Undang Nomor 10 Tahun 2004.

Upaya tersebut sekaligus meneguhkan bahwa Indonesia dalam membangun pondasi bangunan hukumnya berdasarkan pada The
Pure Theory of Law yang disampaikan oleh Hans Kelsen dan theorie vom stufenaufbau der rechtsordnung yang disampaikan oleh Hans Nawiasky. Dua teori tersebut sama-sama menempatkan norma hukum dalam tata susunan yang hierarkis dengan berdasar dan bersumber pada norma hukum yang lebih tinggi, sampai kepada norma tertinggi yaitu Grundnorm-dalam teorinya Kelsen-, dan Staatsfundamentalnorm-dalam teorinya $\mathrm{Na}$ wiasky-. Namun yang harus dipahami ialah bahwa ada perbedaan dalam konsep Grundnorm dan Staatsfundamentalnorm.

Konsep Grundnorm merupakan pengandaian, suatu realitas ideal yang identik dengan keadilan. Adil ialah konsep yang digunakan untuk mengungkap nilai yang cocok dan sesuai dengan sebuah norma. Jadi, adil ialah kata lain dari sah. Grundnorm dalam The Pure Theory of Law nya Kelsen diarahkan untuk mendeskripsikan hukum sebagaimana adanya tanpa mau melayani kepentingan politik siapapun dan menjadi alat ideologis untuk melegitimasi maupun menghilangkan kelompok yang ada. Grundnorm akhirnya menjadi ujung dari keabsahan suatu norma sekaligus menjadi pertimbangan untuk menilai dalam menentukan sah atau tidaknya suatu norma (Dimyati dan Wardiono, 2014:40).

Sedangkan Staatsfundamentalnorm merupakan norma fundamental negara yang menjadi ujung bertolaknya segala norma hukum dalam suatu negara, yang kedudukannya lebih tinggi dibandingkan dengan Aturan Dasar/Pokok Negara. Sebagai norma fundamental dalam sebuah negara, maka dikemukakan melalui bukunya Maria Farida Indrati bahwa itu bisa berubah dan tidak permanen. Kemungkinan berubahnya itu dapat disebabkan oleh kudeta dan revolusi.(Maria Farida Indrati, 2007: 45-48) Oleh karena itu, Staatsfundamentalnorm identik dengan ideologi suatu negara. Ideologi sendiri secara konsep diartikan sebagai ide, gagasan yang diakui kebenarannya oleh suatu bangsa karena dianggap sebagai kepercayaan politik yang kokoh sebagai hasil kesepakatan bersama sebagai landasan dan arah dalam menentukan tujuan kehidupan berbangsa dan bernegara (Soeprapto, 2013: 48).

Pemposisian Pancasila sebagai Grund- 
norm sekaligus sebagai Staatsfundamentalnorm akan menimbulkan misleading seperti yang telah dikemukakan di awal dalam pembentukan norma hukum di Indonesia. Ketika Pancasila sebagai Grundnorm, maka Pancasila menjadi realitas ideal yang digunakan untuk mengungkap nilai yang sesuai dalam sebuah norma. Dengan kata lain, Pancasila merupakan hulu dari suatu norma sekaligus menjadi alat pertimbangan untuk menilai dalam menentukan sah atau tidaknya suatu norma. Sahnya suatu norma itulah yang disebut dengan adil. Oleh karenanya Pancasila sebagai Grundnorm menjadi penentu dalam menentukan adil atau tidaknya suatu norma.

Berbeda dengan Pancasila sebagai Staatsfundamentalnorm. Pancasila sebagai Staatsfundamentalnorm ditempatkan sebagai norma tertinggi yang menjadi batu uji bagi seluruh tatanan norma hukum di Indonesia. Batu uji itulah yang dipercayai sebagai landasan dan arah dalam menentukan tujuan kehidupan berbangsa dan bernegara oleh kesepakatan bersama. Pancasila sebagai Staatsfundamentalnorm menjadi pengikat hegemoni dari suatu bangsa untuk mematuhi penguasa dan menginternalisasi nilai-nilai serta norma yang dibuat oleh penguasa. Jadi, ketika Pancasila diposisikan sebagai Grundnorm, maka seharusnya secara ideal norma hukum yang ada di bawahnya merupakan norma hukum yang adil-bila itu sah-, sehingga norma hukum menjadi sesuatu yang "seharusnya" yang diandaikan oleh seluruh bangsa Indonesia untuk mengatur suatu perilaku. Sedangkan, ketika Pancasila diposisikan sebagai Staatsfundamentalnorm maka norma hukum yang dihasilkannya-karena bersumber padanya- berwarna kepentingan dari pemerintah atau rezim penguasa pada suatu negara, karena itu bisa menjadi alat bagi pemerintah atau penguasa untuk melanggengkan kekuasaannya. Melalui itu pula, norma hukum dapat diciptakan untuk menghilangkan sebagian kelompok yang tidak inginkan oleh pemerintah atau penguasa. Di sinilah terjadi narasi persaingan, tarik-menarik antar kepentingan, yaitu politik dan hukum.

Politik bagi Otto on Bismarck adalah "seni memanfaatkan berbagai kemungkinan"
(Mangesti dan Tanya, 2014: 21). Sedangkan Jouvenel secara lebih jelas mengungkapkan bahwa politik merupakan suatu aktivitas yang membangun, mengonsolidasikan dan tetap mengagregasikan manusia yang terkonsep pada masyarakat yang pada akhirnya bermuara pada kekuasaan daripada paksaan atau persetujuan. Politik dianggap sebagai aktivitas yang lebih meresap dibandingkan dengan tindakan pemerintah yang melingkupi kegiatan manusia secara sosial (Varma, 2010: 183). Lalu hukum dikonsepkan sebagai suatu wujud kongkrit dari segala sesuatu, asas, kaidah atau aturan yang hadir dalam pandangan dan pikiran (Salman dan Susanto, 2008: 7). Pemahaman hukum yang menarik juga terdapat pada buku yang dituangkan oleh Gunawan Setiardja, bahwa hukum bukan hanya yang tertuang dalam keputusan dalam peraturan-peraturan yang dirumuskan atau dalam kesadaran hukum tetapi juga yang terdapat dalam realitas, orang-orang dalam masyarakat, dalam kehendak, pemikiran serta perilaku masyarakat (Setiardja, 1990: 81-83).

Dalam posisi tarik-menarik tersebut, sering sekali itu dipertukarkan dengan konsep politik hukum. Padahal konsep politik hukum sama sekali beda dan tidak dapat mendeskripsikan pola narasi persaingan antara politik dengan hukum. Politik hukum merupakan aktivitas memilih dan cara yang hendak dipakai untuk mencapai suatu tujuan sosial dengan hukum tertentu di dalam masyarakat yang cakupannya meliputi cara apa dan yang mana yang paling baik untuk dipakai dalam mencapai tujuan, kapan waktunya dan melalui cara bagaimana hukum itu perlu diubah serta dapatkah suatu pola yang baku dan mapan dirumuskan untuk membantu dalam memutuskan proses pemilihan tujuan serta cara-cara membantu dalam memutuskan proses pemilihan tujuan serta cara-cara untuk mencapai tujuan tersebut dengan baik (Mahfud MD, 2012: 2).

Membaca pola narasi persaingan tersebut yang dibedakan dari konsep politik hukum, maka politik menjadi sangat bertalian dengan kekuasaan dan ideologi. Ideologi dianggap sebagai alat yang tepat untuk melanggengkan kekuasaan karena telah dianggap sebagai kepercayaan politik yang 
kokoh sebagai hasil kesepakatan bersama menentukan tujuan kehidupan berbangsa dan bernegara. Jadi, ideologi telah dianggap mengandung nilai dan gagasan yang diakui kebenarannya oleh suatu bangsa. Berbeda dengan hukum yang mengandung nilai agar dapat menentukan perilaku yang seharusnya, sehingga pemahaman mengenai baik, buruk, benar dan salah akan "bermain" dalam ranah hukum melalui kesadaran yang terdapat dalam realitas, kehendak dan pemikiran dari orang-orang dalam masyarakat. Jadi, pemosisian Pancasila sebagai Staatsfundamentalnorm akan membentuk pola persaingan antara hukum dengan politik. Inilah yang disebut oleh Mahfud MD sebagai konfigurasi politik terhadap hukum. Ketika ideologi dapat dijadikan sebagai alat untuk membentuk hegemoni agar kekuasaan dapat terjaga terus-menerus dan agar masyarakat dapat terikat sebagai hegemoni dari suatu bangsa untuk mematuhi penguasa dan harus merasa mempunyai serta menginternalisasi nilai-nilai serta norma yang dibuat oleh penguasa, maka hukum sebagai norma menjadi obyek yang dibentuk oleh penguasa untuk menjaga kekuasaannya.

\section{Pola Persaingan Antara Politik dan Hukum Dalam Pembentukan Undang-Undang}

Pembentukan undang-undang saat ini tunduk pada Undang-Undang Nomor 12 Tahun 2011 tentang Pembentukan Peraturan Perundang-undangan. Undang-undang itu mengatur bahwa pembentukan peraturan perundang-undangan meliputi tahapan perencanaan, penyusunan, pembahasan, pengesahan atau penetapan, dan pengundangan. Di dalam masing-masing tahapan itu, terlihat bahwa undang-undang memang dibentuk untuk mengatasi suatu permasalahan dan kebutuhan hukum masyarakat, sehingga dalam proses pembentukannya tidak dapat diboncengi oleh kepentingan-kepentingan golongan tertentu.

Namun di dalam hasilnya, undangundang yang terbentuk justru mengindikasikan diboncengnya kepentingan-kepentingan golongan tertentu, terutama ialah pemilik modal atau kapitalis. Contohnya dalam Undang-Undang tentang Sumber Daya Air dan Koperasi yang akhirnya dibatalkan melalui proses judicial review oleh Mahkamah Konstitusi (MK).

Norma dalam Undang-Undang Nomor 7 Tahun 2004 tentang Sumber Daya Air diselewengkan sehingga cenderung membuka peluang privatisasi dan komersialisasi yang merugikan masyarakat. Ditambah dengan terbitnya Peraturan Pemerintah Nomor 16 Tahun 2005 tentang Pengembangan Sistem Penyediaan Air Minum, peran swasta dalam pengelolaan air semakin tegas dan kuat. Melalui putusannya, MK membatalkan UndangUndang Nomor 7 Tahun 2004 tentang Sumber Daya Air. Dalam pertimbangannya MK menyatakan, sebagai unsur yang menguasai hajat hidup orang banyak, air sesuai Pasal 33 ayat (2) dan ayat (3) haruslah dikuasai negara. Sehingga, dalam pengusahaan air harus ada pembatasan ketat sebagai upaya menjaga kelestarian dan ketersediaan air bagi kehidupan. Setidaknya menurut MK, ada 5 (lima) hal yang menjadi pembatasan pengelolaan air. Pertama, setiap pengusahaan air tidak boleh mengganggu dan meniadakan hak rakyat. Soalnya, selain dikuasai negara, air ditujukan untuk sebesar-besarnya kemakmuran rakyat. Kedua, negara harus memenuhi hak rakyat atas air sebagai salah satu hak asasi manusia, yang berdasarkan Pasal 28I ayat (4) UUD harus menjadi tanggung jawab pemerintah. Ketiganya, MK pengelolaan air pun harus mengingat kelestarian lingkungan. Keempat, sebagai cabang produksi yang penting dan menguasai hajat hidup orang banyak air menurut Pasal 33 ayat 2 UUD 1945 harus dalam pengawasan dan pengendalian oleh negara secara mutlak. Kelima, hak pengelolaan air mutlak milik negara, maka prioritas utama yang diberikan pengusahaan atas air adalah BUMN atau BUMD.

Kondisi yang hampir serupa kisah Undang-Undang Nomor 17 Tahun 2012 tentang Perkoperasian. Undang-undang itu dinyatakan oleh MK dalam pertimbangan putusannya tidak sesuai dengan hakikat susunan perekonomian sebagai usaha bersama dan berdasarkan asas kekeluargaan sebagaimana tercantum dalam Pasal 33 ayat (1) UUD 1945. Pengertian koperasi dalam undangundang itu juga telah dielaborasi sedemiki- 
an rupa, sehingga kewenangan pengawas menjadi sangat luas. Undang-undang itu juga telah mengutamakan skema permodalan materiil dan financial serta mengesampingkan modal sosial yang menjadi ciri fundamental koperasi sebagai suatu entitas khas pelaku ekonomi berdasarkan UUD 1945. Dengan demikian, maka koperasi menjadi sama persis dengan Perseroan Terbatas, dan kehilangan ruhnya sebagai pelaku ekonomi khas bagi bangsa yang berfilosofi gotong-royong. Dengan demikian, maka undang-undang itu dinyatakan bertentangan terhadap konsititusi dan tidak berlaku oleh MK.

Dua contoh tersebut, menjadi realitas menarik untuk mendeskripsikan pola persaingan antara politik dengan hukum dalam pembentukan undang-undang. Undang-undang yang seharusnya menjadi hukum yang mengandung nilai-nilai keadilan dan dibentuk untuk menjadi jalan keluar atau solusi bagi permasalahan yang dhadapi bangsa, justru menjadi alat untuk mengakomodasi kepentingan-kepentingan tertentu. Hal tersebut sekaligus juga menunjukkan bahwa produk undang-undang yang dihasilkan oleh legislator berisi agenda-agenda yang tersembunyi dari pihak atau kelompok tertentu sehingga memicu timbulnya penguasaan oleh sebagian pihak terhadap pihak lain.

Berfikir pada idealitas sebuah hukum, bahwa hukum merupakan kaidah atau norma yang bemanfaat, oleh karena itu penanganannya harus berbeda dengan "sesuatu" yang tidak bermanfaat atau bernilai. Apalagi, hukum menyangkut martabat manusia, maka dalam pembentukannya tidak boleh terlepas dari moral dan nilai keadilan. Dengan kata lain, hukum sebagai instrument yang mengatur tentang martabat manusia tidak boleh menciderai nilai kemanusiaan dengan menampung sejumlah kepentingan-kepentingan tersembunyi untuk mencari keuntungan dengan menegasikan keadilan secara merata bagi orang banyak. Penekanannya ialah, ketika hukum diproduksi, maka politik sebagai proses yang menjadi mesin pencetaknya harus ditempatkan secara ideal, tanpa harus tercampur oleh "tawar-menawar" kepentingan dengan sistem dagang sapi. Kebiasaan tawar-menawar dalam proses pembentukan undang-undang ditonjolkan jika itu untuk memperjuangkan keadilan secara merata kepada seluruh rakyat, sehingga norma dalam undang-undang dapat betul-betul menjadi instrument keadilan yang peka terhadap suatu permasalahan masyarakat.

Realitasnya ialah pembentukan norma dalam undang-undang menjadi suatu tarikmenarik yang alot antara hukum dengan politik. Politik sebagai latar belakang pembentukan hukum cenderung dominan dalam pewarnaan karakter produk hukum yang dihasilkan, sehingga hasilnya, dapat melanggengkan kekuasaan dengan mempermisikan kepentingan sekelompok orang dengan menghilangkan kepentingan orang banyak. Pola-pola persaingan antara hukum dengan politik seperti ini selalu dapat terbaca dalam norma yang tertuang dalam undang-undang. Apalagi politik merupakan seni dalam memanfaatkan berbagai kemungkinan atau suatu aktivitas yang membangun, mengonsolidasikan dan tetap mengagregasikan manusia yang terkonsep pada masyarakat yang pada akhirnya bermuara pada kekuasaan.

Berkaca pada pemahaman konsep politik tersebut, maka politik menjadi sangat bertalian dengan kekuasaan dan ideologi. Ideologi dianggap sebagai alat yang tepat untuk melanggengkan kekuasaan karena telah dianggap sebagai kepercayaan politik yang kokoh sebagai hasil kesepakatan bersama menentukan tujuan kehidupan berbangsa dan bernegara. Jadi, ideologi merupakan kesepakatan yang membentuk kepercayaan politik untuk melanggengkan kekuasan. Kepercayaan politik inilah yang dianggap lebih ampuh ketimbang dengan tindakan konkrit pemerintah itu sendiri. Ideologi sendiri secara konsep diartikan sebagai ide, gagasan yang diakui kebenarannya oleh suatu bangsa, oleh karena itu, dalam teorinya Gramci, ideologi menjadi alat untuk membentuk hegemoni agar kekuasaan dapat terlanggengkan, dan agar masyarakat dapat terikat sebagai hegemoni dari suatu bangsa, sehingga dapat mematuhi penguasa dan menginternalisasi nilainilai serta norma yang dibuat oleh penguasa. Dengan demikian, dalam konteks ini, hukum sebagai norma menjadi obyek yang dibentuk oleh penguasa untuk menjaga kekuasaannya. 
Pancasila selama ini selalu ditempatkan sebagai ideologi dan dasar bernegara bangsa Indonesia. Bahkan melalui berbagai instrument hukum yang diciptakan oleh penguasa dalam rezimnya, Pancasila ditempatkan sebagai sumber dari segala sumber hukum di Indonesia. Berdasarkan instrument-instrument hukum tersebut, dapat disimpulkan bahwa Indonesia sangat terdoktrin oleh The Pure Theory of Law yang disampaikan oleh Hans Kelsen dan theorie vom stufenaufbau der rechtsordnung yang disampaikan oleh Hans Nawiasky. Kedua teori itu berdiri dalam aliran legal positivism atau legisme yang percaya bahwa hukum itu merupakan norma tertulis dalam bentuk peraturan perundangundangan. Dan, hukum hanya dipandang sebagai norma yang tertulis -an sich- dalam peraturan perundang-undangan tanpa melihatnya dengan anasir-anasir lain termasuk moral. Namun, apabila dipahami tentang The Pure Theory of Law nya Kelsen, maka hukum dalam bentuk norma itu tidak terlepas begitu saja dari nilai moral dan keadilan, karena dalam pembentukannya, norma hukum teralir dari Grundnorm yang diyakini sebagai norma dasar yang berfungsi sebagai standar nilai dari keabsahan atau keberlakuan norma secara obyektif. Grundnorm itu sendiri tidak diciptakan melalui kehendak yang sama sekali riil, melainkan diandaikan dalam pemikiran hukum. Pengandaian itu sangat dikaitkan dengan kandungan makna dalam sebuah norma yaitu "kebenaran" dan "keadilan" (Dimyati dan Wardiono, 2014: 41-42).

Berbeda dengan theorie vom stufenaufbau der rechtsordnung yang disampaikan oleh Hans Nawiasky. Norma hukum yang dibentuk, diposisikan sebagai tata susunan yang berhierarki di dalam suatu negara. Norma hukum yang dibentuk itu berdasar dan bersumber pada norma hukum yang lebih tinggi begitu seterusnya sampai pada norma yang tertinggi yang disebut sebagai norma fundamental negara (Staatsfundamentalnorm). Norma fundamental negara (Staatsfundamentalnorm) ini tidak dapat dianggap sama begitu saja dengan Grundnorm yang dimaksud oleh Hans Kelsen dalam teorinya. Hal itu dikarenakan, Kelsen sama sekali tidak mengkaitkan teorinya dengan negara, melainkan berbicara tentang norma secara umum. Dalam konteks Staatsfundamentalnorm, maka itu tidak dapat dipandang sebagai standar nilai bagi keabsahan norma secara obyektif, karena lebih berfungsi sebagai pemberi arah dan tujuan bagi tatanan norma hukum di bawahnya. Dengan demikian, maka Staatsfundaentalnorm lebih bermakna sebagai ideologi yang memberikan "kekuatan" kepada norma-norma di bawahnya agar ditaati oleh masyarakat dalam kehidupan bernegara. Pasalnya demikian, karena Staatsfundamentalnorm merupakan kesepakatan yang membangun kepercayaan politik untuk menentukan kehidupan berbangsa dan bernegara.

Dalam konteks sistem peraturan perundang-undangan di Indonesia, Pancasila yang ditempatkan sebagai sumber dari segala sumber hukum kerap diposisikan antara Grundnorm dan Staatsfundamentalnorm. Padahal jelas bahwa antara Grundnorm dengan Staatsfundamentalnorm memiliki konsep yang berbeda meskipun sama-sama sebagai norma tertinggi dalam tata susunan norma hukum dan berfungsi sebagai sumber dari pembentukan norma hukum di bawahnya. Perbedaan konsep inilah yang akan membuat Pancasila misleading dalam penderivasian nilai-nilainya di dalam norma hukum peraturan perundang-undangan di Indonesia. Pola persaingan antara hukum dengan politik akan kentara ketika Pancasila diposisikan sebagai Staatsfundamentalnorm, karena diposisi itu Pancasila berfungsi sebagai ideologi yang memberikan ide dan gagasan yang telah disepakati dan diterima begitu saja oleh bangsa Indonesia. Sebagai ideologi, maka Pancasila memberikan kepercayaan bagi seluruh bangsa, bahwa nilainya merupakan petunjuk arah dan tujuan bagi bangsa Indonesia. Namun, pengimplementasian ideologi itu sangat bergantung pada jiwa legislator yang mengalirkan melalui norma hukum undang-undang. Hal ini dikarenakan, ideologi dapat menjadi alat untuk melayani kepentingan yag dikehendaki atau bahkan yang tidak dikehendaki. Artinya, legislator dapat saja menggunakan Pancasila untuk melayani kepentingan-kepentingan segelintir pihak melalui norma hukum dalam undang-undang seperti yang terjadi dalam 
Undang-Undang tentang Sumber Daya Alam dan Undang-Undang tentang Perkoperasian yang membonceng kepentingan-kepentingan pemilik modal. Dengan demikian, maka pola persaingan antara hukum dengan politik sangat kentara dalam pembentukan undangundang yang ditentukan oleh legislator dalam memposisikan Pancasila sebagai Staatsfundamentalnorm. Bahkan narasi pola persaingan itu sudah dapat terbaca ketika di dalam proses perencanaan pembentukan undang-undang, yaitu dalam Program Legislasi Nasional (Prolegnas).

Prolegnas merupakan "instrument perencanaan program pembentukan undangundang yang disusun secara terencana, terpadu dan sistematis." Di dalam Prolegnas itulah, program perencanaan pembentukan undang-undang untuk jangka waktu 5 (lima) tahun sudah ditetapkan di awal masa keanggotaan DPR, namun yang terjadi ialah rancangan undang-undang yang sudah direncanakan justru tidak terwujudkan menjadi undang-undang, dan yang tidak terencana menjadi undang-undang justru menjadi undang-undang.

\section{Kemungkinan Pola Persaingan Dalam Menempatkan Pancasila Sebagai Realitas Ideal Sekaligus Ideologi}

Pancasila sejak ditetapkannya pada tanggal 1 Juni 1945 telah ditujukan untuk menjadi landasan atau dasar bagi Negara Indonesia. Sebagai dasar atau landasan negara, maka Pancasila telah ditetapkan menjadi kontrak sosial dasar dan identitas kultural. Pancasila akhirnya menjadi bintang pemandu yang telah disepakati secara bersama karena nilai-nilai yang ditawarkan diyakini bukanlah sesuatu yang asing bagi masyarakat Indonesia. Dari nilai-nilai itulah, Pancasila dapat merumuskan visi masa depan bangsa yang kokoh. Dengan demikian, Pancasila harus diterjemahkan menjadi agenda aksi atau program agar dapat diterapkan dalam lingkungan strategis dan menghadapi tantangan dan masalah yang lebih konkrit.

Namun pada saat ini, Pancasila nilainilainya telah terdegradasi dalam seluruh kehidupan masyarakat, sehingga sulit diterjemahkan dalam lingkungan strategis dan menghadapi masalah yang lebih konkrit. Pancasila dirasakan luntur sebagai identitas bangsa, bahkan tergerus oleh ideologi lain, seperti liberalism. Oleh karena itu, pengembalian posisi Pancasila sebagai dasar atau landasan negara yang ditetapkan menjadi kontrak sosial dan identitas kultural harus diupayakan sedemikian rupa. Tetapi sepertinya, upaya pengembalian itu hanya berada dalam tataran elite tanpa merambah pada grass root yang mengimplementasikan Pancasila kepada masalah-masalah yang lebih konkrit.

Nilai-nilai yang dimiliki oleh Pancasila memang sangat abstrak. Sila pertama yang berbunyi "Ketuhanan Yang Maha Esa" merupakan dasar filsafat bagi Negara Indonesia, dan merupakan sumber nilai serta sumber norma dalam setiap aspek penyelenggaraan negara. Dengan kata lain, setiap aspek penyelenggaraan Negara Indonesia harus sesuai dengan hakikat nilai-nilai yang berasal dari Tuhan baik material maupun spiritual. Material itu ialah mengenai masalah yang menyangkut penyelenggaraan negara, bentuk tujuan negara, tertib hukum dan sistem negara. Sedangkan spiritual, antara lain ialah moral agama dan moral penyelenggaraan negara (Kaelan, 2012: 209). Sila kedua dalam Pancasila yang menyatakan "Kemanusiaan Yang Adil dan Beradab" ingin menunjukkan bahwa negara merupakan lembaga kemanusiaan yang bertujuan untuk mencapai harkat dan martabat manusia serta kesejahteraan lahir maupun batin. Konsekuensi dari nilai yang terkandung dalam sila ini ialah bahwa segala aspek penyelenggaraan negara, sifat-sifat dan keadaan negara harus sesuai dengan hakikat manusia, melindungi hak-hak manusia dan mewujudkannya (Kaelan, 2012: 221). Pancasila dalam sila ketiganya menyatakan "Persatuan Indonesia" ingin menunjukkan bahwa nilai yang dijunjung ialah membentuk suatu persekutuan hidup dengan mempersatukan keanekaragaman yang dimilikinya dalam satu kesatuan integral. Sedangkan, Pancasila melalui sila Keempatnya ialah ingin membentuk nilak bahwa negara terbentuk dari, oleh dan untuk rakyat. Oleh karena itu, negara hakikatnya harus sesuai dengan hakikat rakyat, karena rakyat sebagai pendukung pokok dan asal mula kekuasaan negara. Dengan kata 
lain, negara berkedaulatan rakyat ialah negara demokrasi. Adapun sila Kelima yang berbunyi "Keadilan Sosial Bagi Seluruh Rakyat Indonesia" mengandung nilai bahwa negara Indonesia mempunyai tujuan untuk mewujudkan suatu keadilan dalam hidup bersama dengan melindungi segenap warganya dan seluruh tumpah darah, memajukan kesejahteraan umum serta mencerdaskan kehidupan bangsa. Realisasinya ialah dengan menciptakan peraturan perundang-undangan yang melindungi segenap dan seluruh tumpah darah bangsa Indonesia (Kaelan, 2012: 222-225).

Dalam menciptakan peraturan perundang-undangan, Indonesia telah memiliki panduan atau pedomannya yaitu UndangUndang Nomor 12 Tahun 2011 tentang Pembentukan Peraturan Perundang-undangan. Sebelumnya, Indonesia telah memiliki Undang-Undang Nomor 10 Tahun 2004 tentang Pembentukan Peraturan Perundangundangan. Namun, karena masih terdapat banyak kekurangan dan tidak dapat menampung perkembangan kebutuhan masyarakat, maka undang-undang itu akhirnya digantikan dengan Undang-Undang Nomor $12 \mathrm{Ta}-$ hun 2011 tentang Pembentukan Peraturan Perundang-undangan. Padahal Undang-Undang Nomor 10 Tahun 2004 tentang Pembentukan Perundang-undangan merupakan pengganti juga dari Ketetapan MPR Nomor III/MPR/2000 tentang Sumber Hukum dan Tata Urutan Peraturan Perundang-undangan, dan ketetapan itu juga merupakan pengganti dari Ketetapan MPRS Nomor XX/MPRS/1966 tentang Memorandum DPR-GR Mengenai Sumber Tertib Hukum RI dan Tata Urutan Perundangan RI dan Skema Kekuasaan Di Dalam Negara Republik Indonesia. Di dalam peraturan perundang-undangan tersebut diatur bahwa Pancasila merupakan sumber dari segala sumber hukum di Indonesia. Artinya, dalam pembentukan peraturan perundangundangan, Pancasila menjadi sumber pembentukan norma hukum di Indonesia.

Merefleksikan hal tersebut, maka dapat dipastikan bahwa sistim peraturan perundang-undangan di Indonesia dibangun berdasarkan The Pure Theory of Law yang disampaikan oleh Hans Kelsen dan theorie vom stufenaufbau der rechtsordnung yang disampaikan oleh Hans Nawiasky. Menurut yang tertulis dalam bukunya Khudzaifah Dimyati dan Kelik Wardiono, maka The Pure Theory of Law adalah teori hukum positif yang dimaksudkan untuk mengetahui dan menjelaskan tujuannya tentang apa itu hukum dan bagaimana hukum itu ada. Disebut sebagai The Pure Theory of Law karena hanya menjelaskan hukum dan berupaya membersihkan objek penjelasannya dari berbagai hal yang tidak tersangkut paut dengan hukum. Hal ini dilakukan untuk menghindari pencampuradukan berbagai disiplin ilmu yang mengaburkan esensi ilmu hukum dan meniadakan batas-batas yang ditetapkan padanya. Hukum itu ada menurut teorinya Kelsen karena diciptakan oleh norma hukum yang lebih tinggi dan norma yang lebih tinggi diciptakan oleh norma hukum lagi yang lebih tinggi begitu seterusnya sampai kepada norma dasar yang disebut dengan Grundnorm. Grundnorm ini merupakan realitas ideal yang diidentikkan dengan keadilan, dan keadilan itu akan dicapai bila berkesesuaian dengan hukum positif. Untuk memenuhi keadilan itu, maka dalam pembentukan norma hukum harus bias ideologi dengan efek yang sangat jelas dari segi politik. Oleh karena itu, Grundnorm tidak melayani kepentingan politik siapapun dengan memberikan alat-alat ideologis baik untuk melegitimasi maupun membatalkan kelompok sosial yang ada, karena semua ideologi pada dasarnya berdasarkan kehendak bukan kognisi.

Meskipun digadang-gadang bahwa teori yang disampaikan oleh Hans Kelsen ini dikembangkan oleh muridnya yang bernama Hans Nawiasky dengan theorie vom stufenaufbau der rechtsordnung nya, namun ada hal essensial yang membedakan antara teori yang dismapaikan oleh Kelsen dengan $\mathrm{Na}$ wiasky. Ketika Kelsen memilih untuk menggunakan konsep Grundnorm sebagai norma dasarnya, maka Nawiasky menggunakan konsep Staatsfundamentalnorm. Konsep Staatsfundamentalnorm sendiri digunakan oleh Nawiasky untuk menyatakan bahwa norma hukum yang dimaksudkan ialah norma hukum di dalam suatu negara. Artinya, pembentukan norma hukum itu berada 
di dalam sebuah negara. Staatsfundamentalnorm menjadi norma dasar yang merupakan sumber dari segala sumber hukum pembentukan norma hukum yang ada di dalam suatu negara. Oleh karena itu, ditegaskan melalui bukunya Maria Farida Indrati bahwa Staatsfundamentalnorm bisa berubah dan tidak permanen yang disebabkan oleh kudeta, perang atau revolusi. Dengan demikian, maka Staatsfundamentalnorm lebih identik dengan ideologi suatu negara di bandingkan dengan realitas ideal yang diidentikkan dengan keadilan. Sebagai sebuah ideologi, maka dasarnya ialah kehendak bukan kognisi.

Ideologi merupakan alat untuk mempersatukan manusia sebagai masyarakat pada satu kekuasaan. Ideologi memiliki garis lurus dengan politik. Politik sendiri dari segi konsep merupakan seni memanfaatkan berbagai kemungkinan dan tetap mengagregasikan manusia yang terkonsep pada masyarakat yang pada akhirnya bermuara pada kekuasaan daripada paksaan atau persetujuan. Artinya, politik tetap mengkonsepkan pada terhimpunnya manusia dalam suatu masyarakat di bawah suatu kekuasaan. Politik menjadi sebuah kegiatan untuk tetap menempatkan manusia sebagai masyarakat pada satu kekuasaan.

Hal tersebut sejalan dengan yang dikemukakan oleh Gramci. Menurut Gramci, ideologi menjadi penting agar yang dikuasai mematuhi penguasa dan harus merasa mempunyai serta menginternalisasi nilai-nilai serta norma yang dibuat oleh penguasa. Oleh karena itu, melalui konsep hegemoni, kekuasaan harus dilanggengkan melalui dua perangkat kerja, yaitu aparat pemerintah melalui law enforcement, dan perangkat kerja yang mampu membujuk masyarakat untuk taat pada penguasa melalui kehidupan beragama, pendidikan, kesenian dan keluarga. Berdasarkan itu, maka dapatlah dinyatakan bahwa Pancasila sebagai dasar negara atau landasan hidup bernegara, sesungguhnya telah ditempatkan sebagai ideologi yang mempersatukan bangsa Indonesia melalui kontrak sosial dasar dan identitas kultural. Dengan demikian, jika mengelaborasi dengan teori yang disampaikan oleh Hans Nawiasky, maka tepatlah jika Pancasila diposisikan sebagai
Staatsfundamentalnorm. Sebagai Staatsfundamentalnorm, maka Pancasila sudah selayaknya menjadi sumber bagi pembentukan seluruh peraturan perundang-undangan di Indonesia. Pancasila merupakan pangkal tolak derivasi dari tertib hukum di Indonesia termasuk Undang-Undang Dasar Negara Kesatuan Republik Indonesia Tahun 1945.

Namun, apabila berkaca secara ideal pada pembentukan peraturan perundangundangan, maka ketika Pancasila ditempatkan atau diposisikan sebagai Staatsfundamentalnorm konsekuensinya ialah bahwa produk peraturan perundang-undangan yang dihasilkan akan berisi kehendak, kepentingan yang dikehendaki oleh penguasa atau bahkan menegasikan kepentingan yang tidak dikehendaki oleh penguasa. Oleh karena itu, dapatlah ditunjuk bahwa undang-undang yang pada akhirnya berujung pada meja judicial review, karena kehendak dan kepentingan-kepentingan yang dibonceng begitu memihak, bahkan pada ideologi atau kepentingan kapitalis atau pemilik modal yang isi norma hukumnya bahkan menghilangkan atau melanggar kepentingan-kepentingan orang banyak seperti yang diamantkan oleh Konstitusi. Seperti yang terdapat dalam Undang-Undang Nomor 7 Tahun 2004 tentang Sumber Daya Air yang cenderung membuka peluang privatisasi dan komersialisasi yang merugikan masyarakat. Melalui putusannya, MK membatalkan undang-undang itu dengan menyatakan bahwa sebagai unsur yang menguasai hajat hidup orang banyak, air sesuai Pasal 33 ayat (2) dan ayat (3) haruslah dikuasai negara. Sehingga, dalam pengusahaan air harus ada pembatasan ketat sebagai upaya menjaga kelestarian dan ketersediaan air bagi kehidupan.

Undang-undang lain yang dapat menjadi contoh ialah Undang-Undang Nomor 17 Tahun 2012 tentang Perkoperasian. Undang-undang itu dinyatakan oleh MK dalam pertimbangan putusannya tidak sesuai dengan hakikat susunan perekonomian sebagai usaha bersama dan berdasarkan asas kekeluargaan sebagaimana tercantum dalam Pasal 33 ayat (1) UUD 1945, karena pengertiannya telah dielaborasi sedemikian rupa, sehingga kewenangan pengawas menjadi sangat luas. 
Undang-undang itu juga telah mengutamakan skema permodalan materiil dan financial serta mengesampingkan modal sosial yang menjadi ciri fundamental koperasi sebagai suatu entitas khas pelaku ekonomi berdasarkan UUD 1945. Dengan demikian, maka koperasi menjadi sama persis dengan Perseroan Terbatas, dan kehilangan ruhnya sebagai pelaku ekonomi khas bagi bangsa yang berfilosofi gotong-royong, maka undang-undang itu dinyatakan bertentangan terhadap konsititusi dan tidak berlaku oleh MK.

Kondisi seperti itu merupakan konsekuensi Ketika Pancasila diposisikan sebagai Staatsfundamentalnorm. Hal itu karena, sebagai Staatsfundamentalnorm, maka Pancasila berposisi sebagai ideologi bangsa yang harus memenuhi fungsi untuk melanggengkan kekuasaan dengan membentuk hegemoni. Ideologi ini merupakan senjata ampuh untuk menyatukan manusia-manusia dalam suatu masyarakat di bawah satu kekuasan untuk mentaati pemerintah dan menginternalisasi nilai-nilai yang hendak diwujudkan melalui norma hukum peraturan perundangundangan. Dengan kata lain, Pancasila sebagai ideologi telah mendapat kepercayaan sepenuhnya dari seluruh masyarakat Indonesia sehingga disepakati untuk dilakukan dan diimplementasikan. Namun buntunya lagi, Pancasila sebagai ideologi membuka diri untuk diterjemahkan dalam mengatasi permasalahan konkrit, tetapi penterjemahan itu dapat untuk melayani kepentingan politik sehingga yang timbul ialah pengakomodasian kepentingan yang dikehendaki oleh pembentuk undang-undang, dan menegasikan kepentingan yang tidak dikehendaki. Dengan demikian, sangat terbuka lebar bagi seluruh produk peraturan perundang-undangan di Indonesia untuk diterjemahkan sebagai pengakomodasi kepentingan yang dikehendaki dan yang tidak dikehendaki, sehingga tidaklah mustahil jika timbul undang-undang yang sangat tidak mengalirkan keadilan secara distributif bahkan cenderung memihak.

Pemihakan kepentingan ini mendeskripsikan bahwa ada narasi pola persaingan antara hukum dengan politik, ketika Pancasila diposisikan sebagai Staatsfundamnetalnorm. Persaingan dalam tarik-menarik ke- pentingan antara hukum dengan politik akan sangat kentara dalam pembentukan undangundang. Satu sisi norma hukum yang ingin ditonjolkan untuk mengejar suatu kepastian hukum dalam mengatasi permasalahan di masyarakat, tetapi di sisi lain ada kepentingan-kepentingan yang tidak dapat dinafikan dalam muatan norma hukum di suatu undang-undang. Tarik-menarik antara politik dengan hukum, tidak dapat disama artikan dengan politik hukum. Secara konsep politik hukum berbeda arti dengan politik dan hukum yang saling tarik-menarik satu sama lain.

Politik hukum merupakan arahan atau garis resmi yang dijadikan dasar pijak dan cara untuk membuat dan melaksanakan hukum dalam rangka mencapai tujuan bangsa dan negara. Politik hukum juga merupakan upaya menjadikan hukum sebagai proses pencapaian tujuan negara. Namun tidak dapat dipungkiri, bahwa melalui politik hukum, konfigurasi politik terhadap karakter produk hukum dapat terbaca, sekalipun kontestasinya tidak dapat terlihat, mana yang lebih dominan, apakah politik atau hukum. Pastinya, dalam posisi Staatsfundamentalnorm, Pancasila akan membuka misleading bagi pembentuk undang-undang dalam mengarahkan dan membentuk undang-undang dalam rangka mencapai tujuan bangsa dan negara. Misleading itu dikarenakan, Pancasila dapat ditafsirkan untuk melayani kepentingan-kepentingan penguasa dengan menegasikan muatan idealitas dari norma hukum itu sendiri.

Secara kontras ingin dinyatakan bahwa ketika Pancasila diposisikan sebagai Grundnorm, maka Pancasila akan menjadi suatu realitas ideal yang berisi keadilan tanpa ada kesudian untuk melayani kepentingan siappun. Pancasila sebagai Grundnorm, artinya hanya berfungsi sebagai pemberi keabsahan -an sich- kepada norma-norma hukum yang berada di bawahnya. Isinya hanya sebagai pengandaian sesuatu itu "ada" dan sesuatu yang "seharusnya". Oleh karena itu, undangundang yang dihasilkan pun akan lebih mendistribusikan keadilan, sehingga lah tidak perlu membaca norma hukum atau memahami norma hukum itu menggunakan anasir-anasir lain yang dikhawatirkan akan menghilangkan 
keidealannya itu. Grundnorm sekilas memang dipandang kaku, karena Grundnorm memang menginginkan penjabaran normanorma hukum di bawahnya itu sah. Keabsahan suatu norma hukum itu ialah keadilan. Jadi, norma hukum tidak akan sah apabila materi muatannya tidak mengandung suatu keadilan, dan bila itu tidak sah, maka itu bukanlah hukum. Jadi, sangat tidak dimungkian untuk me-nir-kan persaingan antara politik dengan hukum apabila Pancasila tetap ditempatkan sebagai Grundnorm sekaligus Staatsfundamentalnorm.

\section{Simpulan}

Berdasarkan uraian di atas, maka simpulan yang didapat sebagai berikut. Pertama, Pancasila sebagai Grundnorm atau Staatsfundamentalnorm telah membawa pada pola persaingan antara politik dan hukum, sehingga menjadi bias keadilan, karena konsep Grundnorm merupakan pengandaian, suatu realitas ideal yang identik dengan keadilan. Sedangkan Staatsfundamentalnorm merupakan norma fundamental negara yang menjadi ujung bertolaknya segala norma hukum dalam suatu negara, yang kedudukannya lebih tinggi dibandingkan dengan Aturan Dasar/Pokok Negara. Sebagai norma fundamental dalam sebuah negara, maka dikemukakan melalui bukunya Maria Farida Indrati bahwa itu bisa berubah dan tidak permanen. Kemungkinan berubahnya itu dapat disebabkan oleh kudeta dan revolusi.

Oleh karena itu, Staatsfundamentalnorm identik dengan ideologi suatu negara. Pemposisian Pancasila sebagai Grundnorm sekaligus sebagai Staatsfundamentalnorm akan menimbulkan misleading seperti yang telah dikemukakan di awal dalam pembentukan norma hukum di Indonesia. Ketika Pancasila sebagai Grundnorm, maka Pancasila menjadi realitas ideal yang digunakan untuk mengungkap nilai yang sesuai dalam sebuah norma. Dengan kata lain, Pancasila merupakan hulu dari suatu norma sekaligus menjadi alat pertimbangan untuk menilai dalam menentukan sah atau tidaknya suatu norma. Sahnya suatu norma itulah yang disebut dengan adil. Oleh karenanya Pancasila sebagai Grundnorm menjadi penentu dalam menentukan adil atau tidaknya suatu norma. Berbeda dengan Pancasila sebagai Staatsfundamentalnorm. Pancasila sebagai Staatsfundamentalnorm ditempatkan sebagai norma tertinggi yang menjadi batu uji bagi seluruh tatanan norma hukum di Indonesia.

Batu uji itulah yang dipercayai sebagai landasan dan arah dalam menentukan tujuan kehidupan berbangsa dan bernegara oleh kesepakatan bersama. Pancasila sebagai Staatsfundamentalnorm menjadi pengikat hegemoni dari suatu bangsa untuk mematuhi penguasa dan menginternalisasi nilai-nilai serta norma yang dibuat oleh penguasa. Jadi, ketika Pancasila diposisikan sebagai Grundnorm, maka seharusnya secara ideal norma hukum yang ada di bawahnya merupakan norma hukum yang adil-bila itu sah-, sehingga norma hukum menjadi sesuatu yang "seharusnya" yang diandaikan oleh seluruh bangsa Indonesia untuk mengatur suatu perilaku. Sedangkan, ketika Pancasila diposisikan sebagai Staatsfundamentalnorm maka norma hukum yang dihasilkannya-karena bersumber padanya- berwarna kepentingan dari pemerintah atau rezim penguasa pada suatu negara, karena itu bisa menjadi alat bagi pemerintah atau penguasa untuk melanggengkan kekuasaannya. Melalui itu pula, norma hukum dapat diciptakan untuk menghilangkan sebagian kelompok yang tidak inginkan oleh pemerintah atau penguasa.

Di sinilah terjadi narasi persaingan, tarik-menarik antar kepentingan, yaitu politik dan hukum. Jadi, pemosisian Pancasila sebagai Staatsfundamentalnorm akan membentuk pola persaingan antara hukum dengan politik. Inilah yang disebut oleh Mahfud MD sebagai konfigurasi politik terhadap hukum. Ketika ideologi dapat dijadikan sebagai alat untuk membentuk hegemoni agar kekuasaan dapat terjaga terus-menerus dan agar masyarakat dapat terikat sebagai hegemoni dari suatu bangsa untuk mematuhi penguasa dan harus merasa mempunyai serta menginternalisasi nilai-nilai serta norma yang dibuat oleh penguasa, maka hukum sebagai norma menjadi obyek yang dibentuk oleh penguasa untuk menjaga kekuasaannya.

Kedua, pola persaingan antara hukum 
dengan politik dalam pembentukan undangundang ialah Contohnya dalam UndangUndang tentang Sumber Daya Air dan Koperasi yang akhirnya dibatalkan melalui proses judicial review oleh Mahkamah Konstitusi (MK). Norma dalam Undang-Undang Nomor 7 Tahun 2004 tentang Sumber Daya Air diselewengkan sehingga cenderung membuka peluang privatisasi dan komersialisasi yang merugikan masyarakat. Melalui putusannya, MK membatalkan Undang-Undang Nomor 7 Tahun 2004 tentang Sumber Daya Air. Dalam pertimbangannya MK menyatakan, sebagai unsur yang menguasai hajat hidup orang banyak, air sesuai Pasal 33 ayat (2) dan ayat (3) haruslah dikuasai negara. Sehingga, dalam pengusahaan air harus ada pembatasan ketat sebagai upaya menjaga kelestarian dan ketersediaan air bagi kehidupan. Hampirlah serupa kisah Undang-Undang Nomor 17 Tahun 2012 tentang Perkoperasian. Undang-undang itu dinyatakan oleh MK dalam pertimbangan putusannya tidak sesuai dengan hakikat susunan perekonomian sebagai usaha bersama dan berdasarkan asas kekeluargaan sebagaimana tercantum dalam Pasal 33 ayat (1) UUD 1945.

Pengertian koperasi dalam undangundang itu juga telah dielaborasi sedemikian rupa, sehingga kewenangan pengawas menjadi sangat luas. Undang-undang itu juga telah mengutamakan skema permodalan materiil dan financial serta mengesampingkan modal sosial yang menjadi ciri fundamental koperasi sebagai suatu entitas khas pelaku ekonomi berdasarkan UUD 1945. Dengan demikian, maka koperasi menjadi sama persis dengan Perseroan Terbatas, dan kehilangan ruhnya sebagai pelaku ekonomi khas bagi bangsa yang berfilosofi gotong-royong. Dengan demikian, maka undang-undang itu dinyatakan bertentangan terhadap konsititusi dan tidak berlaku oleh MK.

Ketiga, pola persaingan dalam menempatkan pancasila sebagai realitas ideal sekaligus ideologi ialah tidak mungkin tercapai, karena sebagai Staatsfundamentalnorm, Pancasila berposisi sebagai ideologi bangsa yang harus memenuhi fungsi untuk melanggengkan kekuasaan dengan membentuk hegemoni. Dengan kata lain, Pancasila se- bagai ideologi telah mendapat kepercayaan sepenuhnya dari seluruh masyarakat Indonesia sehingga disepakati untuk dilakukan dan diimplementasikan. Namun buntunya lagi, Pancasila sebagai ideologi membuka diri untuk diterjemahkan dalam mengatasi permasalahan konkrit, tetapi penterjemahan itu dapat untuk melayani kepentingan politik sehingga yang timbul ialah pengakomodasian kepentingan yang dikehendaki oleh pembentuk undang-undang, dan menegasikan kepentingan yang tidak dikehendaki.

Dengan demikian, sangat terbuka lebar bagi seluruh produk peraturan perundangundangan di Indonesia untuk diterjemahkan sebagai pengakomodasi kepentingan yang dikehendaki dan yang tidak dikehendaki, sehingga tidaklah mustahil jika timbul undang-undang yang sangat tidak mengalirkan keadilan secara distributif bahkan cenderung memihak. Pemihakan kepentingan ini mendeskripsikan bahwa ada narasi pola persaingan antara hukum dengan politik, ketika Pancasila diposisikan sebagai Staatsfundamnetalnorm.

Persaingan dalam tarik-menarik kepentingan antara hukum dengan politik akan sangat kentara dalam pembentukan undangundang. Satu sisi norma hukum yang ingin ditonjolkan untuk mengejar suatu kepastian hukum dalam mengatasi permasalahan di masyarakat, tetapi di sisi lain ada kepentingan-kepentingan yang tidak dapat dinafikan dalam muatan norma hukum di suatu undang-undang. Tarik-menarik antara politik dengan hukum, tidak dapat disama artikan dengan politik hukum. Secara kontras ingin dinyatakan bahwa ketika Pancasila diposisikan sebagai Grundnorm, maka Pancasila akan menjadi suatu realitas ideal yang berisi keadilan tanpa ada kesudian untuk melayani kepentingan siappun.

Pancasila sebagai Grundnorm, artinya hanya berfungsi sebagai pemberi keabsahan -an sich- kepada norma-norma hukum yang berada di bawahnya. Isinya hanya sebagai pengandaian sesuatu itu "ada" dan sesuatu yang "seharusnya". Oleh karena itu, undang-undang yang dihasilkan pun akan lebih mendistribusikan keadilan, sehingga lah tidak perlu membaca norma hukum atau 
memahami norma hukum itu menggunakan anasir-anasir lain yang dikhawatirkan akan menghilangkan keidealannya itu. Grundnorm sekilas memang dipandang kaku, karena Grundnorm memang menginginkan penjabaran norma-norma hukum di bawahnya itu sah. Keabsahan suatu norma hukum itu ialah keadilan. Jadi, norma hukum tidak akan sah apabila materi muatannya tidak mengandung suatu keadilan, dan bila itu tidak sah, maka itu bukanlah hukum. Jadi, sangat tidak dimungkian untuk me-nir-kan persaingan antara politik dengan hukum apabila Pancasila tetap ditempatkan sebagai Grundnorm sekaligus Staatsfundamentalnorm.

\section{Daftar Pustaka}

Ali, As'd Said. 2009. Negara Pancasila: Jalan Kemaslahatan Berbangsa. Jakarta: Pustaka LP3ES Indonesia.

Beilharz, Peter. 2005. Teori-Teori Sosial: Observasi Kritis Terhadap Para Filosofi Terkemuka. Yogyakarta: Pustaka Pelajar.

Dimyati, K dan Kelik Wardiono. 2014. Paradigma Ra- sional Dalam Ilmu Hukum: Basis Epistemologis Pure Theory Of Law Hans Kelsen. Yogyakarta: Genta Publishing.

Kaelan. 2012. Problem Epistemologi Empat Pilar Berbangsa dan Bernegara. Yogyakarta: Paradigma.

Mahfud MD. Moh. 2012. Membangun Politik Hukum, Menegakkan Konstitusi. Jakarta: PT. Rajagrafindo Persada.

Mangesti, Yovita A. dan Bernard L. Tanya. 2014. Moralitas Hukum. Yogyarakarta: Genta Publishing.

Salman, Otje dan Anthon F. Susanto. 2008. Teori Hukum: Mengingat, Mengumpulkan dan Membuka Kembali. Bandung: Refika Aditama.

Setiardja, A. Gunawan. 1990. Dialektika Hukum dan Moral Dalam Pembangunan. Yogyakarta: Kanisius.

Soeprapto, Maria Farida Indrati. 2007. Ilmu PerundangUndangan: Jenis, Fungsi dan Materi Muatan. Yogyakarta: Kanisius.

Soeprapto. 2013. Pancasila. Jakarta; Konstitusi Press. Varma, SP. 2010. Teori Politik Modern. Jakarta: Raja Grafindo Persada.

Undang-Undang Dasar 1945.

Undang-Undang Nomor 12 Tahun 2011 tentang Pembentukan Peraturan Perundang-undangan. 